\title{
Two new species of the millipede genus Caucasodesmus Golovatch, 1985 from the Crimea, Russia (Diplopoda, Polydesmida, Trichopolydesmidae)
}

\section{Ава новых вида диплопод рода Caucasodesmus Golovatch, 1985 из Крыма (Россия) (Diplopoda, Polydesmida, Trichopolydesmidae)}

\author{
S.I. Golovatch ${ }^{1} \&$ D. VandenSpiegel ${ }^{2}$ \\ С.И. Головач ${ }^{1}$, А. ВанденШпигель ${ }^{2}$
}

\footnotetext{
${ }^{1}$ Institute for Problems of Ecology and Evolution, Russian Academy of Sciences, Leninsky prospekt 33, Moscow 119071, Russia. ${ }^{1}$ Институт проблем экологии и эволюции РАН, Ленинский проспект, 33, Москва 119071, Россия.

${ }^{2}$ Musée Royal de l'Afrique Centrale, B-3480 Tervuren, Belgique.
}

KEY WORDS: millipede, Caucasodesmus, taxonomy, new species, cave, key, Crimea, Caucasus.

КЛЮЧЕВЫЕ СЛОВА: диплопода, Caucasodesmus, таксономия, новые виды, пещера, ключ, Крым, Кавказ.

ABSTRACT. A key is given to all four species of the Crimeo-Caucasian genus Caucasodesmus, including two new described from Crimean caves: $C$. svetlanae sp.n. and C. turbanovi sp.n. The generic diagnosis is slightly emended as well.

РЕЗЮМЕ. Приведён ключ для всех четырёх видов крымско-кавказского рода Caucasodesmus, включая двух новых, описываемых из крымских пещер: C. svetlanae sp.n. и C. turbanovi sp.n. Дополнен родовой диагноз Caucasodesmus.

\section{Introduction}

The millipede fauna of the Crimea is currently known to contain only 15 species from 12 genera, eight families and six orders [Golovatch, 2008, 2011]. Of these, only very few species, e.g. Megaphyllum tauricum (Attems, 1907), Amblyiulus kovali Golovatch, 2008 and Caucasodesmus tauricus Golovatch, 2011, are likely Crimean endemics [see also Lazányi \& Vagalinski, 2013; Evsyukov \& Golovatch, 2013]. In contrast, most species show more or less vast (Euro-)Mediterranean distributions, including several presumed anthropochores [Golovatch, 2008].

The more so important is the present discovery of two new millipedes in caves of the Crimea. Unlike probably all other faunal elements, these new species belong to what seems to be a palaeoendemic genus, Caucasodesmus Golovatch, 1985. This genus has recently been reviewed and shown to encompass only two species: C. inexpectatus Golovatch, 1985, the type species from a cave in North Ossetia, Caucasus [Golovatch, 1984/85], and C. tauricus, from a cave in the Crimea [Golovatch, 2011].
Material and methods

Material serving as the basis for the present contribution was collected by hand in two caves in the Crimea, both lying in different karsts. All material is donated to the Zoological Museum, State University of Moscow (ZMUM + entry number), Russia. The samples are stored in 70-75\% ethanol. Specimens for scanning electron microscopy (SEM) were air-dried, mounted on aluminium stubs, coated with gold and studied using a JEOL JSM-6480LV scanning electron microscope.

\section{Descriptions}

Caucasodesmus svetlanae

Golovatch et VandenSpiegel sp.n.

Figs 1-20

HOLOTYPE: OT (ZMUM م2447), Russia, Crimea, Ai-Petri Karst Region, Karadagh Forest, Cave Kuznetsova (= Koryta), 8.III.2014, leg. I.S. Turbanov.

PARATYPES: $3 \sigma^{7} \sigma^{7}, 3$ OP, 4 juv. (ZMUM $\left.\rho 2448\right), 1 \sigma^{7}$ (SEM), same data, together with holotype.

NAME. Honours Svetlana Bogdanenko, one of the most active members of the "Zelenye Kamneyedy" Speleological Club, Sevastopol, Crimea.

DIAGNOSIS. Differs by the slightly sigmoid solenophore being considerably longer than the solenomere (Figs 15-17). See also Key below.

DESCRIPTION. Length ca 5-6 mm, width of midbody pro- and metazonae $0.5-0.6$ and $0.7-0.8 \mathrm{~mm}\left(\sigma^{7}\right.$,, ), respectively. Coloration entirely pallid, only sometimes very faintly pinkish.

Body with 19 segments. Tegument mainly dull, at most slightly shining, texture very delicately alveolate and scaly. Head densely pilose throughout; epicranial suture distinct, but thin; isthmus between antennae ca 1.5 times broader than 

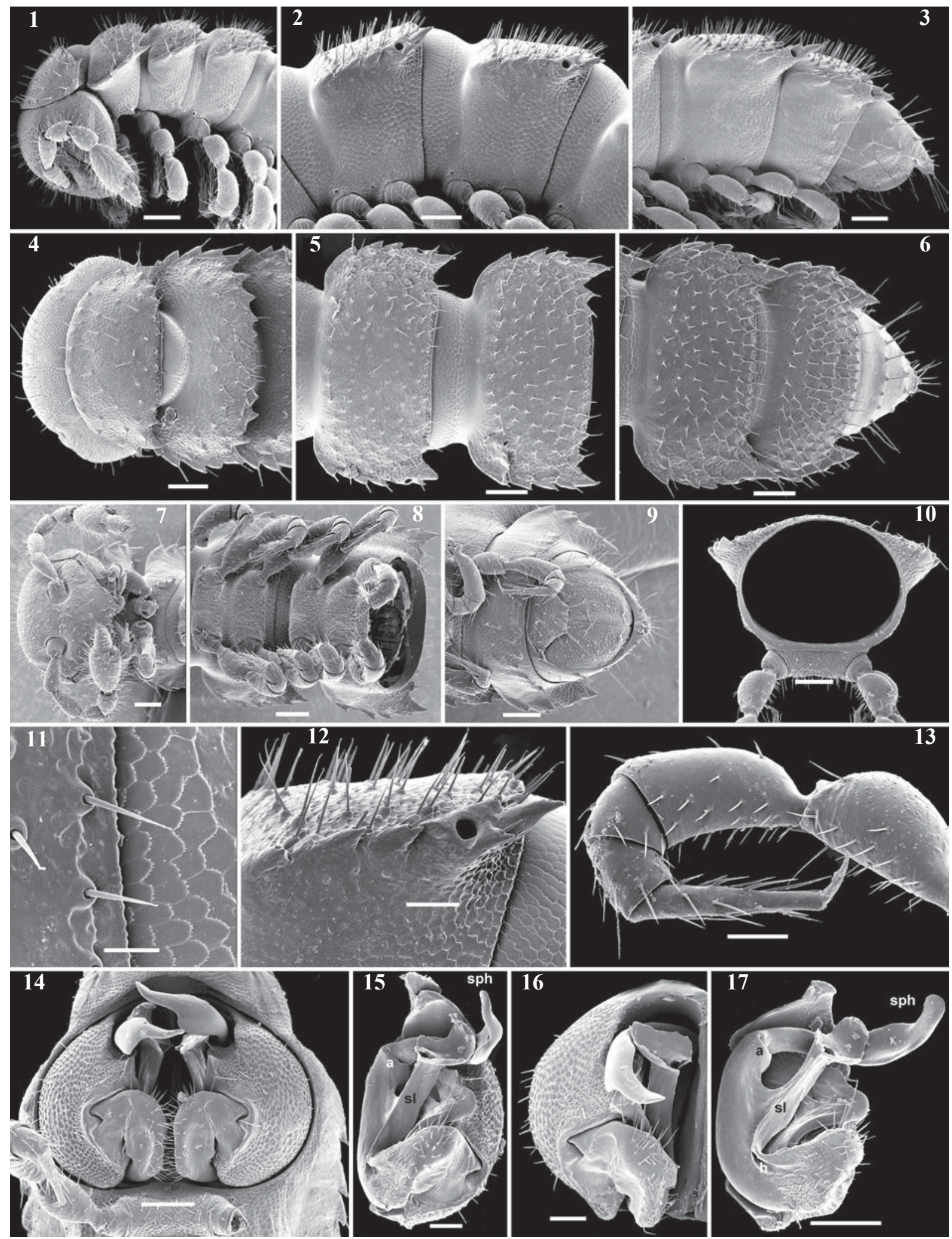

Figs 1-17. Caucasodesmus svetlanae Golovatch et VandenSpiegel sp.n., $\bigcirc^{7}$ paratype: 1, 4,7 - anterior part of body, lateral, dorsal and ventral views, respectively; 2, 5,8 - midbody segments, lateral, dorsal and ventral views, respectively; 3, 6, 9 - posterior part of body, lateral, dorsal and ventral views, respectively; 10 - cross-section of a midbody segment, caudal view; 11 - limbus and microstructure of adjacent tergal setae and prozona, dorsal view; 12 - midbody poriferous metatergum, lateral view; 13 - midbody leg, lateral view; 14 - both gonopods in situ, ventral view; 15-17 — right gonopod, caudal, subventral and mesal views, respectively. Scale bars: 0.1 (1-10), 0.05 (12$14,17), 0.02(11)$ and $0.01 \mathrm{~mm}(15-16)$ 

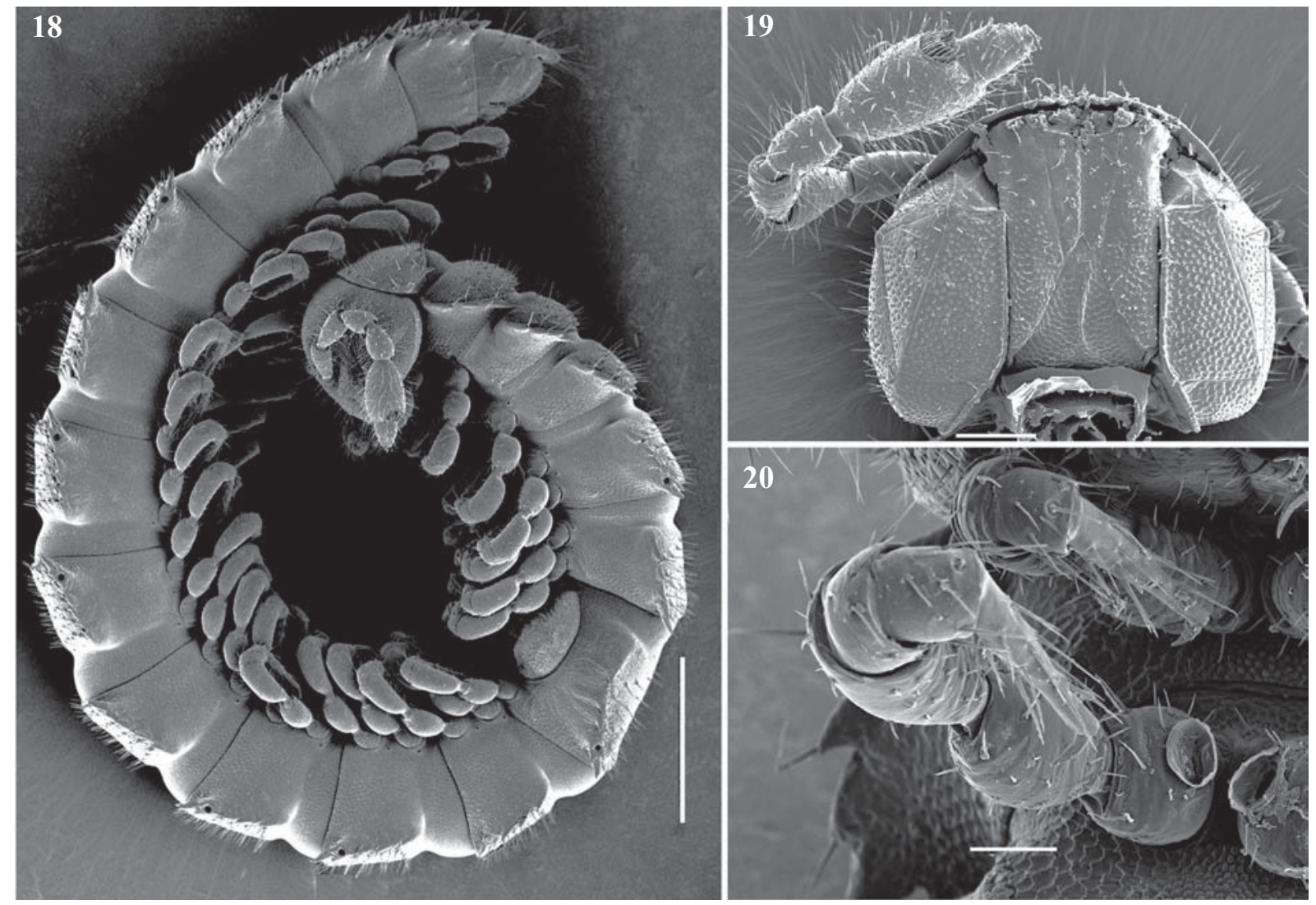

Figs 18-20. Caucasodesmus svetlanae Golovatch et VandenSpiegel sp.n., $0^{7}$ paratype: 18 - habitus, lateral view; 19 — head, ventral view; 20 - right legs 1 and 2, ventral view. Scale bars: 0.5 (18), 0.1 (19) \& $0.05 \mathrm{~mm}(20)$.

Pис. 18-20. Caucasodesmus svetlanae Golovatch et VandenSpiegel sp.n., паратип О७: 18 - общий вид, сбоку; 19 - голова, снизу; 20 - правые ноги 1 и 2, снизу. Масштаб: 0,5 (18), 0,1 (19) и 0,05 мм (20).

length of antennomere 1 , still broader than diameter of antennal socket (Fig. 7). Antennae rather short, evidently clavate due to a considerably enlarged antennomere 6 , slightly overreaching segment 2 dorsally; antennomeres 2,3 and 6 longest, subequal in length (Figs 1,7); only antennomere 6 with a large, compact, roundish, distodorsal group of bacilliform sensilla (Figs 1, 19). Genae squarish, gnathochilarium without peculiarities (Fig. 19).

In width, collum $<$ segment $2=3<$ head $=4<5=16\left(\bigcirc^{7}\right)$, or head $=$ collum $=$ segment $2=4<5=16(+)$, thereafter body gradually tapering towards telson. Paraterga moderately developed, starting with collum, subhorizontal to slightly declivous, set high, but always lying slightly below a faintly convex dorsum, devoid of shoulders frontally (Figs 1-10, 18). Caudal corner of collum and postcollum paraterga invariably spiniform, pointed, increasingly clearly extending behind rear tergal margin (Fig. 18). Lateral edge of paraterga with neither a marginal groove nor a callus, mostly with 5-6, very clear, setigerous indentations. Pore formula normal, ozopores evident, round, located laterally in front of caudalmost incision (Fig. 12). Collum and following metaterga beset with numerous, rather irregular, medium-sized setae borne on minute knobs, these knobs growing a little more prominent in caudalmost rows; polygonal bosses missing (Figs 1-10, 18). Stricture between pro- and metazonae wide, shallow and smooth. Limbus very thin, very faintly microdenticulate, nearly smooth (Fig. 11). Pleurosternal carinae absent (Figs 1-3, 18). Epiproct short, conical, directed caudoventrally; pre-apical papillae small (Figs 3, 6, 9). Hypoproct trapeziform, setiferous papillae at caudal corners evident, rather well separated (Fig. 11).

Sterna broad, without modifications, poorly setose (Figs 7-9). Epigynal ridge very low. Legs rather short and stout (Figs 13, 18), ca 1.2-1.3 $\left(\mathrm{O}^{7}\right)$ or $0.9-1.0(+)$ times as long as midbody height; + legs slightly slenderer; $O^{\prime}$ legs with clearly enlarged and micropapillate prefemora and femora; tarsi especially long and slender, claw long, ca $1 / 4$ length of tarsus; sphaerotrichomes missing (Fig. 13). Gonapophyses on $0^{7}$ coxae 2 vestigial, lamellar, cup-shaped (Figs 7, 20).

Gonopod aperture subcordiform, broader than $\sigma^{7}$ prozona 7 (Fig. 14). Gonopods (Fig. 15-17) rather complex, coxae large, subglobose, micropapillate and setose laterally, totally devoid of cannulae; telopodites quite deeply sunken into a rather prominent gonocoel, only apical parts being moderate-

Рис. 1-17. Caucasodesmus svetlanae Golovatch et VandenSpiegel sp.n., паратип $\sigma^{7}: 1,4,7$ — передняя часть тела, соответственно сбоку, сверху и снизу; 2, 5, 8 - средняя часть тела, соответственно сбоку, сверху и снизу; $3,6,9$ - задняя часть тела, соответственно сбоку, сверху и снизу; 10 - поперечный разрез через среднетуловищный сегмент, сзади; 11 - лимбус и микроструктура соседних тергальных щетинок и прозонита, сверху; 12 - среднетуловищный несущий пору метатергит, сбоку; 13 - среднетуловищная нога, сбоку; 14 - оба гонопода in situ, снизу; 15-17 - правый гонопод, соответственно сзади, почти снизу и изнутри. Масштаб: 0,1 (1$10), 0,05(12-14,17), 0,02$ (11) и 0,01 мм (15-16). 
ly exposed; each telopodite deeply biramous, strongly curved caudad; prefemoral (= densely setose) parts short and held subtransversely to main body axis, but acropodites lying subparallel to each other; telopodite consisting of a shorter, mesal, rather loose, tubiform solenomere (sl) (= endomere) and a clearly longer, lateral, slightly sigmoid, apically round-
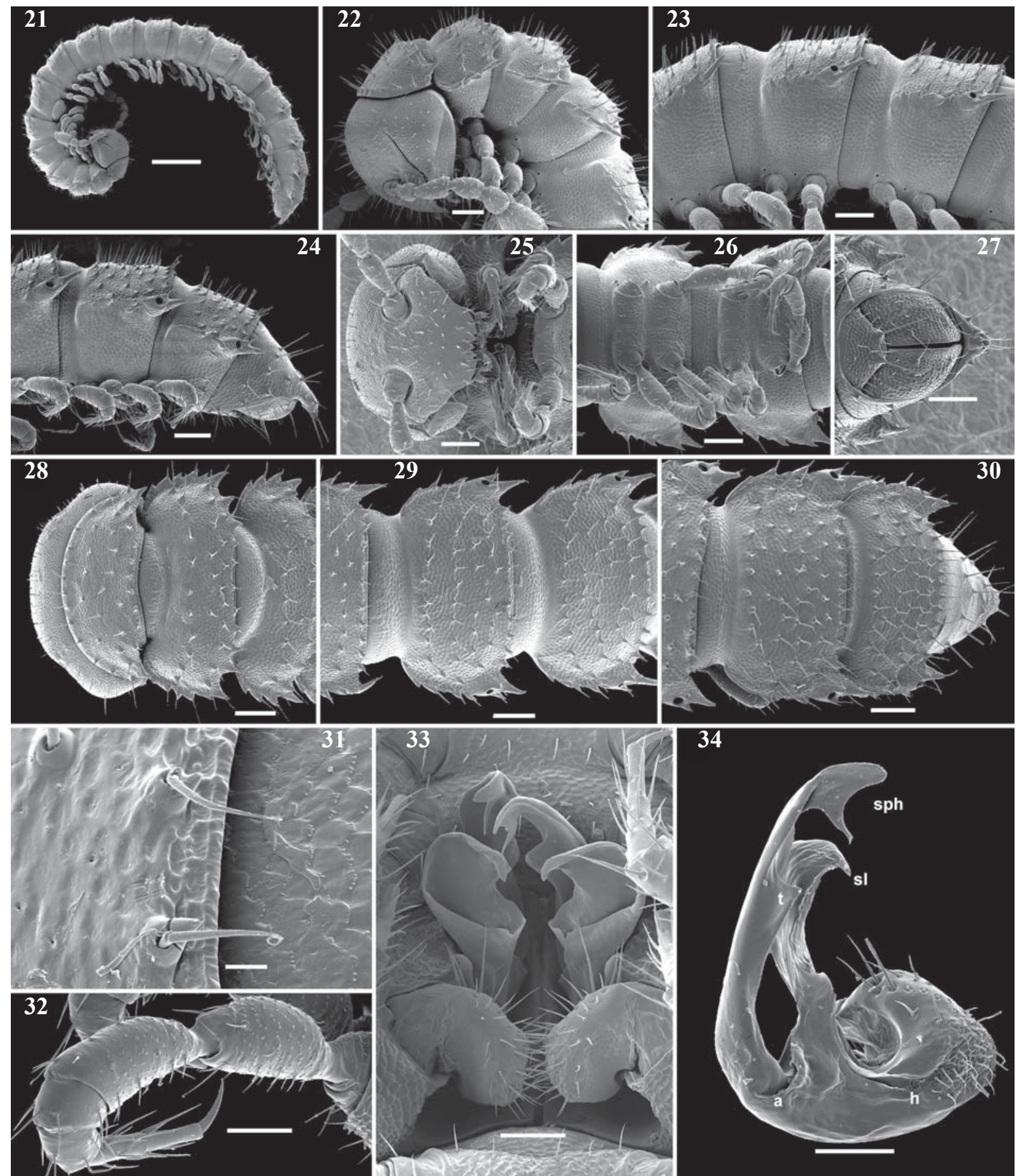

Fig 21-34. Caucasodesmus turbanovi Golovatch et VandenSpiegel sp.n. 0 paratype: 21 — habitus, lateral view; 22, 25, 28 — anterior part of body, lateral, ventral and dorsal views, respectively; 23, 26, 29 - midbody segments, lateral, ventral and dorsal views, respectively; $24,27,30$ - posterior part of body, lateral, ventral and dorsal views, respectively; 31 - limbus and microstructure of adjacent tergal setae and prozona, dorsal view; 32 - midbody leg, lateral view; 33 - both gonopods in situ, ventral view; 34 - left gonopod, mesal view. Scale bars: 0.5 (21), $0.1(22-30), 0.05(32-34) \& 0.01 \mathrm{~mm}(31)$.

Рис. 3. Caucasodesmus turbanovi Golovatch et VandenSpiegel sp.n., паратип О': 21 - обший вид, сбоку; 22, 25, 28 — передняя часть тела, соответственно сбоку, снизу и сверху; 23, 26, 29 - средняя часть тела, соответственно сбоку, снизу и сверху; $24,27,30$ задняя часть тела, соответственно сбоку, снизу и сверху; 31 - лимбус и микроструктура соседних тергальных щетинок и прозонита, сверху; 32 - среднетуловищная нога, сбоку; 33 - оба гонопода in situ, снизу; 34 - левый гонопод, изнутри. Масштаб: 0,5 (21), 0,1 $(22-30), 0,05(32-34)$ и 0,01 мм (31) 
ed solenophore (sph), or exomere; sl starting with a typical hole (h) for a cannula to hinge into, but ending up by a broad lamellar cup, orifice of seminal groove being unusually wide and lying at cup bottom; sph with a remarkable articulation (a) near base.

\section{Caucasodesmus turbanovi \\ Golovatch et VandenSpiegel sp.n.}

Fig. 21-34

HOLOTYPE: $\sigma^{7}$ (ZMUM 2449), Russia, Crimea, Karabi Karst Region, near Pass Chigenitra, Cave Tuakskaya (= Ful-Koba), 7.VI.2014, leg. I.S. Turbanov.

PARATYPES: $60^{7} \sigma^{7}, 5$ 오, (ZMUM 02451$), 10^{7}$ (SEM), same data, together with holotype; $1 \mathrm{O}^{2}, 2$ 우 (ZMUM $\rho 2450$ ), same cave, 8.V.2013, leg. I.S. Turbanov.

NAME. Honours Ilya Turbanov, of the Institute of the Biology of the Southern Seas, Sevastopol, Russia, also one of the most active members of the "Zelenye Kamneyedy" Speleological Club, Sevastopol, Crimea, who has collected this and some other diplopods in the Crimea and the Caucasus.

DIAGNOSIS. Differs by the shorter and clearly bifid solenophore. See also Key below.

DESCRIPTION. Length ca 5-6 mm $\left(\sigma^{7}, 9\right)$, width of midbody pro- and metazonae $0.4-0.6$ and $0.6-0.8 \mathrm{~mm}$, respectively. Coloration entirely pallid.

All characters as in C. svetlanae sp.n. (Fig. 21-32), except as follows.

Tergal pilosity a little less dense and more regular (Fig. 28-30).

Gonopod telopodite (Fig. 33-34) consisting both of a shorter, mesal, rather loose solenomere (sl) ending up by a broad lamellar flare and of a slightly longer, lateral, clearly bifid solenophore (sph) showing a mesal tooth (t) in distal 1/3; sl likewise starting with a typical hole (h) for a cannula to hinge into, but orifice of seminal groove unusually wide and lying at flare bottom; sph also with a remarkable articulation (a) near base.

\section{Conclusions}

The genus Caucasodesmus has hitherto been characterized, among other things, by 20 body segments and the simultaneous loss both of a cannula on the coxa and of a seminal groove on the telopodite of the gonopod [Golovatch, 1984/85, 2011]. However, the new Crimean species show 19 body segments and, as revealed by SEM, a rather loose, but prominent solenomere (sl) supporting a seminal groove. The gonopod does consist of two branches, the shorter, mesal one being a solenomere (= endomere) while the longer, lateral one representing a solenophore (sph), or exomere. What seems particular about the solenomere in the Crimean Caucasodesmus is that it starts with a typical hole (h) for a cannula to hinge into, but ends up by a broad lamellar cup or flare so that the orifice of the seminal groove is unusually wide and lies at the bottom of the cup. In addition, SEM has revealed a peculiar articulation (a) present near the base of the solenophore. We strongly suspect that structure $\mathbf{d}$ in $C$. tauricus, described as a process, actually represents an articulation. Moreover, like the other Crimean spe-

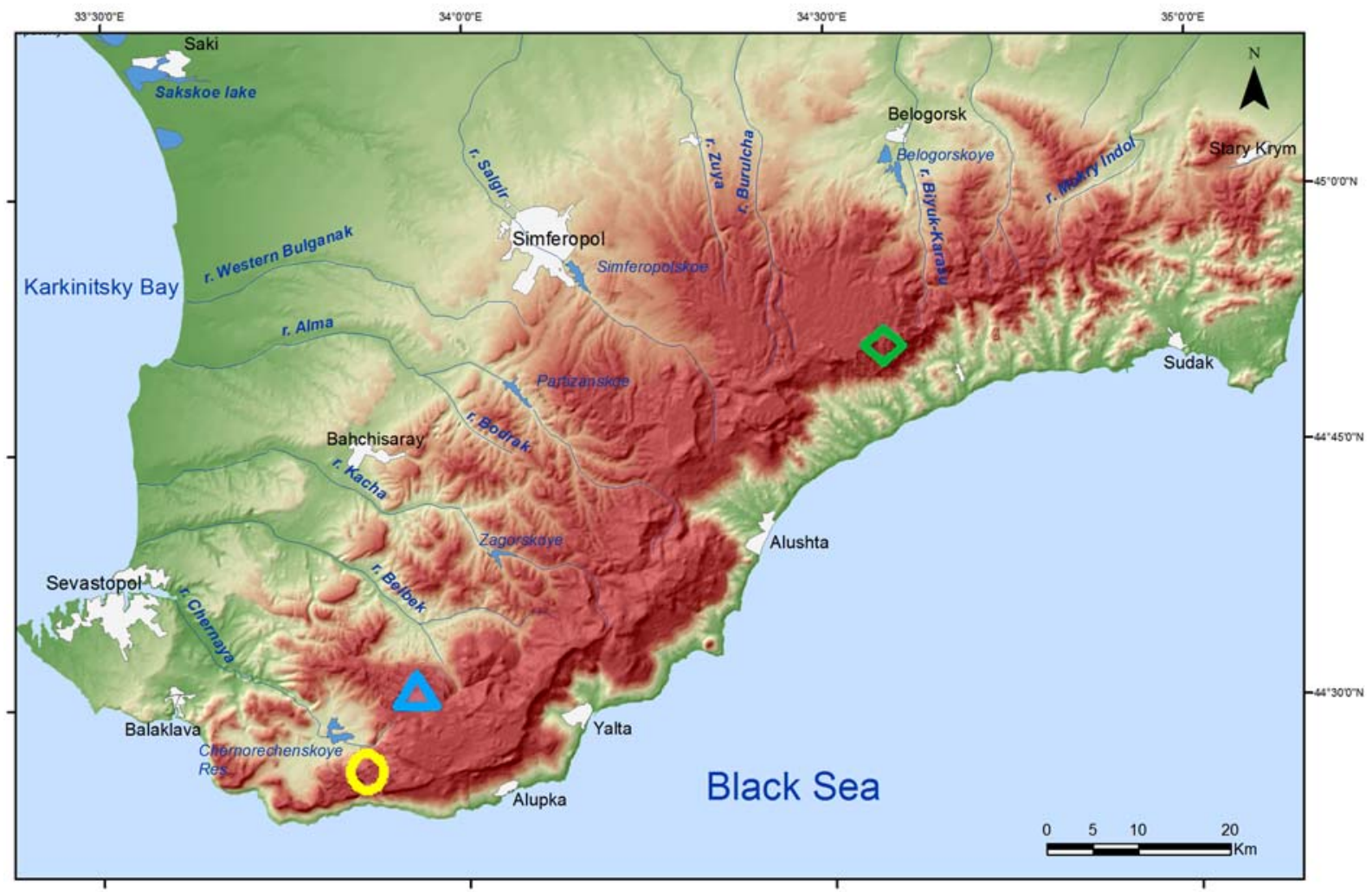

Map. Distribution of Caucasodesmus species in the Crimea: green diamond - C. turbanovi sp.n., yellow circle - C. svetlanae sp.n., blue triangle $-C$. tauricus.

Карта. Распространение видов Caucasodesmus в Крыму: зеленый ромб - C. turbanovi sp.n., желтый кружок - C. svetlanae sp.n., синий треугольник - C. tauricus. 
cies, C. tauricus has 19 , not 20, body segments, as one can see from the pictures of the holotype alone [cf. Golovatch, 2011].

These features invite certain amendments to the diagnosis of this genus to be made. As regards its body, it counts 19 or 20 segments in both sexes. Concerning gonopod structure, it must read as follows [cf. Golovatch, 2011]: Gonopod coxae large, subglobose, lacking cannulae. Telopodites falcate, deeply bipartite, prefemoral (= densely setose) part held subtransversely to main body axis, but acropodites lying subparallel to each other; larger, lateral branch a solenophore (sph), or exomere, sometimes showing a parabasal articulation (a); smaller, mesal branch, or endomere, either totally devoid of a seminal groove or often a rather loose tubiform solenomere (sl) supporting a seminal groove, the latter's orifice then being unusually wide and located at bottom of an expanded cup or flare forming sl apex.

The gap, morphological as well as geographical, between three Crimean species, on the one hand, and the North Caucasian type species, on the other hand, appears to be quite considerable. This is clearly reflected in the key below. However, we still believe all four species to represent a single genus, when the known congeners from the Crimea are mainly distinguishable by minor details of gonopod structure.

The distribution of Caucasodesmus species in the Crimea is clearly allopatric, since each appears to be restricted to its own karst (Map). This pattern agrees quite well with the modern regionalization of the Crimea's karsts which recognizes three main karst regions in the peninsula [Vakhrushev, 2009]. Thus, $C$. turbanovi sp.n. occurs solely in the Karabi Karst Region, whereas $C$. svetlanae sp.n. and $C$. tauricus, even though inhabiting different caves, share the same AiPetri Karst Region as delimited by Vakhrushev [2009]. From a biospeleological viewpoint, however, the AiPetri Region, the largest and most complex among the karsts of the Crimea also morphologically, can generally be subdivided into the western, central and eastern parts. Each basically supports much its own cave fauna as well [I. Turbanov, personal communication]. That no Caucasodesmus has yet been revealed in the third, Chatyrdagh Karst Region seems to be a promising sign for continuing the biospeleological explorations in the Crimea.

\section{A KeY to CAUCASODESMUS SPECIES:}

1(2) Body with 20 segments. Only three transverse regular rows of tergal setae per metatergum. Seminal groove totally absent, a small lamellar lobe (= endomere) instead of a solenomere. Tip of solenophore (= exomere) fringed. North Ossetia, cave ............................. C. inexpectatus

2(1) Body with 19 segments. Metatergal setation far more abundant and less regular. Seminal groove traceable along a mesal tubiform solenomere showing an apical cup- or flare-shaped expansion. Tip of solenophore not fringed. Crimea, caves

3(4) Solenophore considerably longer than solenomere, slightly sigmoid (Figs 15-17) .................. C. svetlanae sp.n.

4(3) Solenophore only barely longer than solenomere, curved

5(6) Smaller: length ca 5-5.5 mm, width of midbody metazonae $0.6-0.8 \mathrm{~mm}$. Solenophore ( $\mathbf{s p h}$ ) rather slender, clearly bifid, also with a mesal shelf-like apophysis in distal $1 / 3$ (Figs 33, 34) C. tubanovi sp.n.

6(5) Larger: length ca $8 \mathrm{~mm}$, width of midbody metazonae 1.5 $\mathrm{mm}$. Solenophore claviform, devoid of processes ... C. tauricus

ACKNOWLEDGEMENTS. We are most grateful to Ilya Turbanov, Sevastopol, Crimea, for his advice, help and enthusiasm. He, together with his fellow speleoclub members, very actively collects cave fauna in the Crimea and western Caucasus and kindly sends us his material for treatment.

\section{References}

Evsyukov A., Golovatch S.I. 2013. Millipedes (Diplopoda) of the Rostov-on-Don Region, southern Russia // Arthropoda Selecta. Vol.22. No.3. P.207-215.

Golovatch S.I. 1984/85. Two new genera of cave-dwelling millipedes (Diplopoda), with remarks on the millipede fauna of West Caucasian caves // International Journal of Speleology. Vol.14. P.39-50.

Golovatch S.I. 2008. On three remarkable millipedes (Diplopoda) from the Crimea, Ukraine // International Journal of Myriapodology. Vol.1. P.97-110.

Golovatch S.I. 2011. The millipede genus Caucasodesmus Golovatch, 1985, with the description of a new species from the Crimea, Ukraine (Polydesmida, Diplopoda, Trichopolydesmidae) // ZooKeys. Vol.93. P.1-8.

Lazányi E., Vagalinski B. 2013. Redefinition of the millipede subgenus Megaphyllum sensu stricto Verhoeff, 1894 and neotype designation for Megaphyllum austriacum (Latzel, 1884) (Myriapoda: Diplopoda: Julida: Julidae) // Zootaxa. Vol.3741. No.1. P.55-100.

Vakhrushev B.A. 2009. [Regionalization of karst of the Crimean Peninsula] // Speleologiya i Karstologiya. Simferopol. No.3. P.39-46 [in Russian]. 